\title{
The whale watched and whaled: exploring the orderings of a complex environmental issue through the lens of rubbish theory
}

\author{
Benedict E. Singleton ${ }^{1}$ \\ University of Gothenburg, Sweden
}

\begin{abstract}
The political ecological study of environmental issues is often concerned with the interactions of diverse actors, leading to accounts of different, conflicting worldviews. While different epistemological and ontological standpoints are covered, there is consensus that environmental issues are simultaneously social and material, and that worldviews differ. In this article, I argue Michael Thompson's rubbish theory can be usefully employed to compare and contrast environmental perspectives ultimately rooted in conflicting epistemological and ontological understandings of a situation. Rubbish theory describes the categorization of objects into durables, transients and rubbish, and movements between these categories. Rubbish theory focuses on how objects are restricted in their movement and how this reflects the distribution of power and status in society. Two aspects of a society may then be assessed: 1) its value system, and 2) the extent to which different groups may alter that value system. Dynamic changes in these two aspects are then traceable. As an example of extant environmental conflicts rooted in different worldviews, this article focuses on historic and contemporary issues around the consumption of whale meat. Focusing upon whaling and whale-watching, I argue that historic and contemporary conflicts manifest different orderings and that these comprise different epistemological standpoints, which as value systems are comparable within rubbish theory.
\end{abstract}

Key words: Political ontology; cosmopolitics; environmental conflict; social theory; cetaceans

\section{Résumé}

L'écologie politique des problèmes environnementaux est souvent concernée par les interactions d'acteurs divers, conduisant à des récits de visions du monde différentes et conflictuelles. Si différents points de vue épistémologiques et ontologiques sont abordés, il existe un consensus sur le fait que les questions environnementales sont à la fois sociales et matérielles. Les visions du monde sont différentes. Dans cet article, je soutiens que la « théorie des déchets » (rubbish theory) de Michael Thompson peut être utilisée pour comparer et contraster les perspectives environnementales finalement enracinées dans les compréhensions épistémologiques et ontologiques d'une situation. La « théorie des déchets » décrit la catégorisation des objets en biens durables, transitoires et déchets, et les mouvements entre ces catégories. La « théorie des déchets » se concentre sur la façon dont les objets sont limités dans leur mouvement et comment cela reflète la répartition du pouvoir et du statut dans la société. Deux aspects d'une société peuvent alors être évalués : 1) son système de valeurs, et 2) la mesure dans laquelle différents groupes peuvent modifier ce système de valeurs. Les changements dynamiques dans ces deux aspects sont alors traçables. En tant qu'exemple de conflits environnementaux existants enracinés dans différentes visions du monde, cet article se concentre sur les problèmes historiques et contemporains liés à la consommation de viande de baleine. En me concentrant sur la chasse à la baleine et l'observation des baleines, je soutiens que les conflits historiques et contemporains manifestent des ordres différents. Ceux-ci comprennent différents points de vue épistémologiques, qui, en tant que systèmes de valeurs, sont comparables au sein de la théorie des déchets.

Mots clés: ontologie politique; cosmopolitique; conflit environnemental; théorie sociale; cétacés

\section{Resumen}

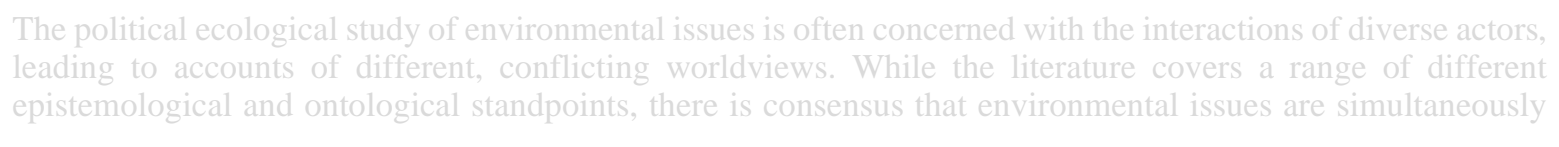

1 Dr. Benedict E. Singleton, Postdoc, School of Global Studies, University of Gothenburg, Sweden. Email: Benedict.singleton "at" gu.se. Thankyou to the referees and editors. 


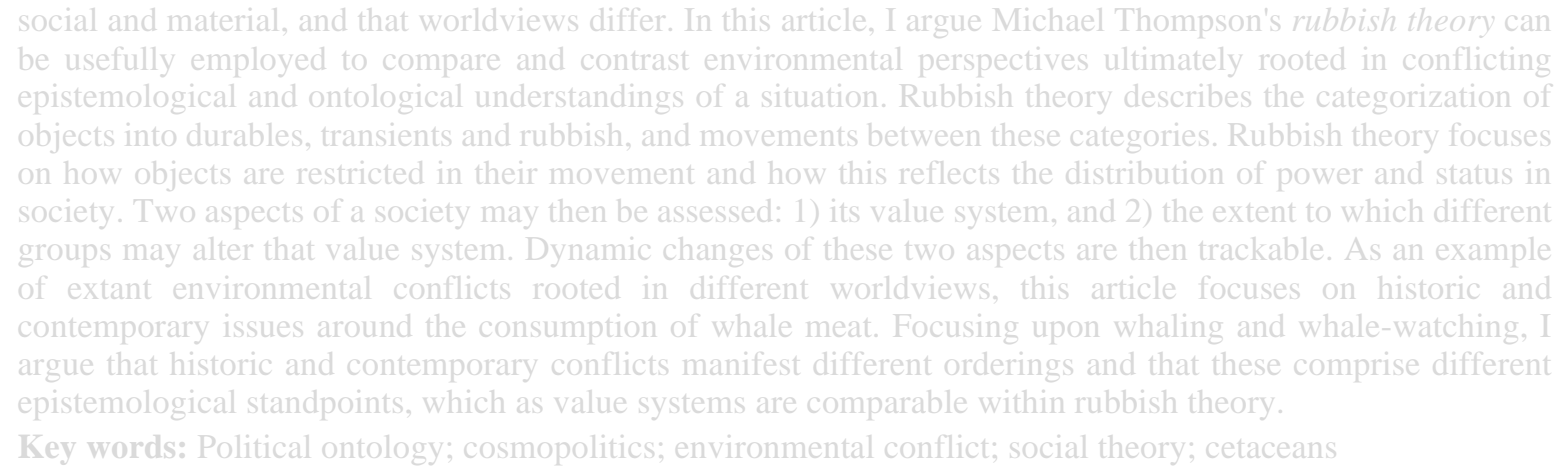

\section{Introduction}

The apparent incommensurability of different worldviews, manifesting as clashing discourses, has been studied in contemporary social scientific research (Thompson 2002; Dryzek 2013) or as 'political ontologies' (e.g. Blaser 2009). While this literature covers a considerable body of different epistemological and ontological standpoints, they share the idea that environmental issues are simultaneously social and material. They identify the gaps between different worldviews - there is a pluriverse rather than a universe (Bormpoudakis 2019). Dissonance between standpoints is then depicted at the heart of a large number of environmental issues and conflicts. This obviously presents an analytical challenge to political ecology. If each conflict entails a coming together of particular, dynamic, historically and geographically situated, sociomaterial orderings of reality, then these are unique, presenting challenges to generalization (cf. Burman 2017). Social scientists have begun to engage with this issue, taking a variety of stances. For example, Blaser examines "crossings... points of encounter between practices" (2018: 57). Likewise, Ludwig seeks to identify "property clusters" around particular objects (2016: 44). Both these writers are suggesting that there are times of overlap between multiple worldviews/discourses/ontologies. What at occurs at these overlap points is often highly politicized, with "cosmopolitical" conflicts being the result (Blok 2011; Latour 2004; cf. de la Cadena 2010; Escobar 1999; Viveiros de Castro 2004).

In this article, I offer Michael Thompson's Rubbish Theory as a tool for examining different worldviews. Rubbish theory focuses specifically upon these ordering processes, providing a schema and a language within to interpret different ordering systems that intends to minimize the violence done to different knowledge systems (Thompson 1979[2017]). This schema thus provides one path towards the possibility of 'shared worlds' rather than binary oppositions between different actors locked in conflicts (cf. Blaser 2018; Bormpoudakis 2019; Ludwig 2016). Rubbish theory explores how certain things come to be valued, while others discarded; why one thing is worth fighting for while others can be happily destroyed.

This article applies rubbish theory to the case of historic and contemporary conflicts around whales. Most famously conflicts relate to whaling (whale-hunting) practices around the world, but there are also disagreements over the practice of whale-watching. Discussions of whales and whaling often highlight the dysfunctional nature of global management regimes. Indeed, whaling conflicts in particular are depicted as "spiraling moral confrontation[s]" (Blok 2008: 61), with the actors involved operating with disparate moral understandings of whales, and acts relating to them (Blok 2011). Conflicts around whales are described as the meeting of different ordering (of reality) projects, within which various objects are interpellated (see the next Section). In this conceptualization, social life is considered a series of practices that collectively order the world, bringing different aspects of an infinite, messy reality into prominence and highlighting or hiding different pieces of information. Whales thus emerge at different times as distinct objects, as collections of objects or as part of greater ordering systems such as ecosystems or even nature as a whole.

The article is ordered thus: in the next section, I introduce rubbish theory and then describe my methodological approach. I then examine different orderings of whales and the human activities that go on around them. Discussion thus moves from the days of industrial whaling for oil, through the rise of the "green 
movement" and then on to contemporary issues around whaling and whale watching. Through this, I highlight how very different ordering systems are interpretable within rubbish theory, producing novel insights around flash-point issues.

\section{Introducing rubbish theory}

Rubbish theory appears at first to be simple; however, it arguably contains some very radical ideas (particularly regarding mainstream economic thought), a feature it shares with the closely related 'cultural theory' as created by anthropologist Mary Douglas and her collaborators (6 and Richards 2017). This branch of sociological theory explores how particular worldviews are coproduced with particular ways of organization (called institutions), which occurs at every social scale - from individual to international. As with cultural theory, rubbish theory focuses upon orderings of different objects within particular worldviews and the ways that people deal with 'matter out of place' (e.g. Douglas 1966[2002]). In this understanding, conflict often emerges around conflicting orderings, but also how to deal with matter out of place. In this Section, I present the basic elements of rubbish theory as relevant to understanding the changing movements of objects around whales that have occurred through history, from the $19^{\text {th }}$ century to the present. I do not attempt to describe the whole theory, which includes models of change linked to catastrophe theory, nor its links to cultural theory. The theory's originator (Michael Thompson) has already written the book on that (1979[2017], Figure 1). I argue that the changing nature of conflicts around whales can be seen in terms of the changing nature of valuation systems. Thompson published Rubbish Theory in 1979, and few copies of the book were printed, although the text was translated into other languages. It has gained a new lease of life following its 2017 republication, with two new chapters, with increasing application beyond the obvious (e.g. processes of managing waste). Recent research has applied the theory to topics as diverse as heritage tourism (Fisher \& Smiley 2016), archaeology (Marwato 2019), cancer tumor donation (Morrell et al. 2011) and literary theory (Chappell 2013).

Rubbish theory is concerned with the orderings of objects:

The basic idea is that physical objects have certain important properties imposed on them as a result of processes of human social life, and, conversely, that if these properties were not conferred upon them then human social life itself would not be possible. Since people are physical objects, they too are subject to the same process. Nor does it stop here. Ideas, since they must always be generated and communicated in a social context, are also constrained so as to become, to a somewhat variable extent, thing-like. I will now use the word 'object' to refer, not just to physical objects (including people), but to ideas as well. (Thompson 1979[2017]: 88)

In essence, people try to enact order upon infinite, dynamic and chaotic reality as the only way they can make sense of it. Rubbish theory utilizes three basic categories to model flows of objects (Figure 1), which have slightly different characters. Two initial object categories are specified, which both have value but different temporal characters:

- A durable object is considered something that largely gains value over time (e.g. a work of fine art). Whilst obviously impossible (in a cosmic sense), durables are considered by social actors to be largely eternal (Thompson 1979[2017]: 113). Indeed, ironically durables often require both material and symbolic maintenance work.

- A transient object, by contrast, loses value over time (e.g. many foodstuffs or a car), eventually becoming worthless.

So far, so simple, but there is also a third category - rubbish - which differs from the other two by having zero value. As Figure 1 shows, it is the fate of all transient things to eventually become rubbish (or garbage). However, there is more to it than this. Rubbish theory argues that rubbish is also that which remains outside of any ordering. No human model of the world can incorporate infinite reality. Rubbish is thus residual reality 
unaccounted for by human ordering. It is thus argued to be largely an implicit category. Rubbish theory makes two important claims from this. Firstly, that rubbish as an implicit category has largely been omitted from most economic thinking and, linked to this, rubbish actually plays an important role as a potential source of durable objects. Thus, items that were at one stage considered transient, worthless and vulgar may be transformed through various social practices into valuable durable items (Thompson 1979[2017]). Examples of this include objects made by unsuccessful artists that become hailed as masterpieces after their death, or household items casually cast aside later becoming valued archaeological finds.

A third feature of the implicit rubbish category is that people largely only become aware of it when it's in the wrong place and people's responses are often embodied, emotional and physical, resembling responses to breaking taboos or social mores (Thompson 1979[2017]). Societies thus invest considerable social, political and economic resources to ensuring that rubbish ends up in the 'correct' place. This most obviously applies to littering and the punishments handed out to those who create of drop litter in many societies. It may apply to people as well, indeed most racist systems involve ordering groups of people. For example, in Sweden, the country where I live, a recent public debate has occurred around the presence of tiggare (beggars), often of Romanian or Bulgarian Roma origin, who have become an ever-present feature soliciting money outside many grocery shops. These people's presence presents a direct challenge to many Swedish orderings of society. In mainstream Swedish public discourse, there should not be any beggars or homeless; the state takes care of everybody, and should safely house people, placing them out of sight and mind. Many Swedish people thus find being asked to give money very difficult, provoking feelings of anger and embarrassment. The presence of tiggare obviously generates different reactions. These include charitable initiatives, but also verbal abuse of beggars, as I have witnessed. The town of Eskilstuna took the extraordinary step of banning the act of begging in particular public places (Gagnert Dalgren 2019). All of these can be interpreted as efforts to remove 'rubbish' from public view.
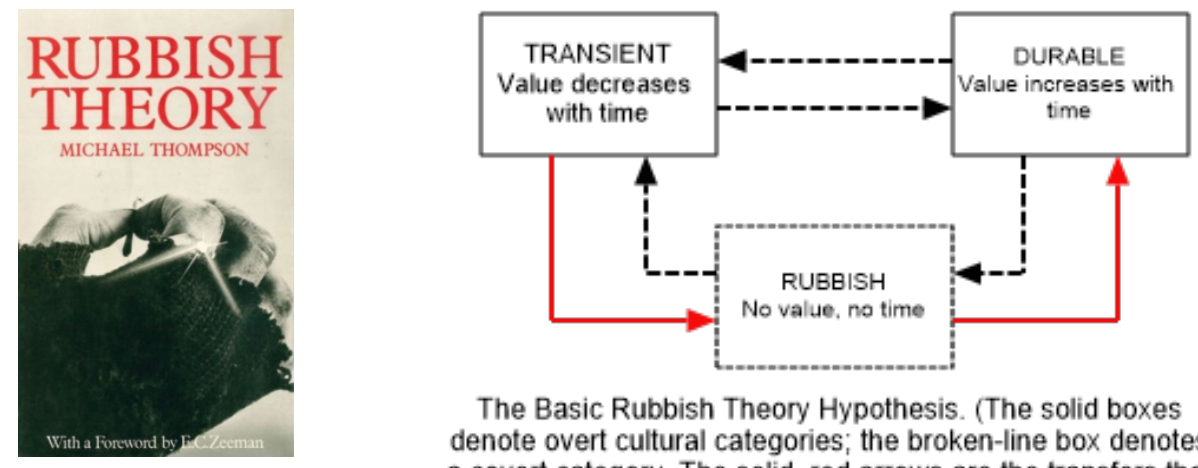

The Basic Rubbish Theory Hypothesis. (The solid boxes denote overt cultural categories; the broken-line box denotes a covert category. The solid, red arrows are the transfers that theoretically happen; the broken, black ones the transfers that theoretically do not happen because they contradict the value and/or time direction that define the various categories).

Figure 1: Rubbish Theory (1979), and The Rubbish Theory Hypothesis. Adapted from Thompson (2017: 4)

Conflicts around tiggare also illustrate an important point about the language of rubbish theory, which is potentially problematic. Rubbish theory analysis should not be understood as endorsing iniquitous essentialisms made about particular social groups. However, rubbish theory is not a decolonial theory of itself (cf. Bell 2018). Applying concepts from one paradigm such as 'rubbish' or 'durable' to another inherently entails the possibility of violence towards other orderings/worldviews/thought systems/cosmologies/ontologies when 
it assumes people are talking about the same things (cf. Ludwig 2016; Nadasdy 2011). This risk applies to any theory that aims to move beyond the very specific. However, readers should be aware that the application of terms like 'rubbish' does not entail authorial moral acceptance or endorsement of a particular ordering system (cf. Bell 2018). ${ }^{2}$ Rubbish theorists are not claiming that there is one authoritative ordering system, rather that all ordering systems can be interpreted within the Rubbish Theory framework. In this article I hope to show that the framework can be used sensitively, minimizing the risk of violence. I would like to draw on a fascinating example from one critic's own text, used to illustrate the apparent incommensurability of different ordering systems. Citing Deborah Bird Rose, Bell (2018: 115) writes:

As Rose explains, her aboriginal teachers rarely pick up after themselves because 'they do not seek to erase themselves' (2003, p. 62). Indeed, within Australian indigenous cultures, selferasure is a harmful act, and self-inscription is a means of telling a story of 'knowledgeable action', an action that invokes the mutual relationship between land, people and things: 'the remains of the dinner camps tell the stories of how they went to that place and called out to the country, and how the country fed them' (Rose 2003, p. 62).

To me, with my limited knowledge of Australian Aboriginal peoples and thought, this does not seem to be at all in conflict with rubbish theory. Rather than activities and the leftovers from transient activities deteriorating into rubbish, instead, the relationship between land, people and things is the durable object. Dropped items or litter, clearly understood by many in the West as rubbish, have other meanings in the case Bell cites. Presumably, however there are various actions needed to maintain the people-land relationship and likewise there are other objects that are considered transient and that disappear from view into the category of rubbish. Likewise, there may well be status differentials linked to the flow of objects ${ }^{3}$, even if these objects are unrecognized by the western eye. As such, I am skeptical of the assertion that valuations of different objects are purely a product of "colonialism and ... the project of modernity" (Bell 2018: 114) even if, obviously, colonialism has hugely and shockingly influenced and transformed ordering systems globally.

Moving on, humans expend considerable social and creative energy on imagining and enforcing these orderings, and so there will be considerable variability between orders regarding the collective social processing of objects. The only real limits to variation are the limitations of material reality itself. However, as one cannot exist apart from orderings, it can be very difficult to identify when that which has been excluded from a particular ordering will reassert itself. Residual 'rubbish' suddenly and devastatingly makes its presence felt in disasters. For example, investigations of the Challenger and Columbia space shuttle disasters highlighted how institutional ordering practices ignored glaringly obvious (with hindsight) information that would have pointed to looming catastrophe (Challenger broke apart 73 seconds after lift-off in 1986: Columbia suffered a blow from a detached piece of its foam insulation, a known fault, that led to breakup of the craft during re-entry in 2003). In these cases, 'deviant' information was 'normalized' to prevent it disturbing the dominant ordering of reality upon which the shuttle program was based (Vaughan 2016). Rubbish theory does not posit a static world: reality is dynamic. As in new materialist accounts of studying waste, things in the world have effects independent of human social constructions, and this will influence whether they are recognized as 'objects' (cf. Bell 2018). While enacting orderings is inherently political, such orderings and the properties of different objects will affect how easily they may be pushed into the categories offered by rubbish theory.

\footnotetext{
${ }^{2}$ Bell also asserts, while including rubbish theory in a general criticism of waste studies, that rubbish theory leaves out perspectives on wastes from the Global South (broadly defined as "encompassing politically, environmentally and economically vulnerable communities") (2018: 99). I'm unconvinced by the validity of this point regarding rubbish theory. Thompson explicitly discusses Indian sociology and caste systems and Tiv kinship, while also examining the role of object valuations within UK class systems (1979[2017]). However, it is certainly true that Thompson, while having worked and lived in South Asia, is from the Global North.

${ }^{3}$ Or to put it more philosophically, "property clusters" that are recognizable within rubbish theory's framework (cf. Ludwig 2016).
} 
Nonetheless, it is fair to say that a potential weakness of rubbish theory is a blindness to non-human agency. Likewise, rubbish theory has been criticized for not saying enough about the practice of value- creation (Parsons 2007). In my view, a framework of practice would limit rubbish theory's application beyond specific cases. For example, a focus on specific practices transforming an old car into a desired collectible object would potentially limit rubbish theory's applicability to, say, Tiv kinship systems (both are examples in Thompson's book). The lack of attention to non-human agency, or to practice, are best ameliorated by taking a "clumsy" research approach and considering "social and political processes from a variety of normative viewpoints" (Verweij, Thompson \& Engel 2011: 246), drawing thoroughly upon a wide variety of data and sources. There also needs to be a humbleness and an awareness among rubbish theory practitioners that sometimes the theory cannot explain everything, and that there may be times when alterity is indeed too radical. However, this does not mean one should not try, lest one fall into "fetishization of otherness" (Vigh and Sausdal 2014: 56).

The model described in Figure 1 illustrates the movement of objects that should or should not happen under 'normal/expected' circumstances within this model. Within rubbish theory, it represents an 'ideal type' of a particular society (a "class society") - one where transient items deteriorate to rubbish and may become raw material for durables. However, 'forbidden' transactions do periodically occur. Without wishing to go into too much detail: where this is small scale (e.g. scrap dealers selling rubbish among themselves) it seldom threatens the social order. By contrast, rubbish theory argues that an action that obviously disturbs the logic of a whole system tends to elicit strong social reaction. For example, the 2001 destruction of the Buddhas of Bamiyan (a UNESCO World Heritage Site) by the Taliban was a provocative act, in part, because it constituted a deliberate act of category vandalism. It rendered a durable (functionally infinite) object transient. Likewise, other transactions (e.g. durable to transient) may manifest during moments of social disorder or breakdown (Thompson 1979[2017]).

The final component of rubbish theory brings in power. In the basic rubbish theory hypothesis (Figure 1), certain transactions (e.g. transient to rubbish) 'should' occur in contrast with those that do not (e.g. transient to durable without passing through the rubbish stage). The extent that objects are allowed to flow from transient to rubbish to durable reflects the relationship between social status and material resources within that society. These can be placed along two axes: levels of status differentials (stratification) and amount of competition (between individuals and groups) to assert ordering systems (Figure 2). The model illustrated by Figure 1 entails a controlled transfer of rubbish into durable objects. In this form of society, power to convert rubbish into durables is the privilege of particular social groups and indeed the act of doing so is interpellated with these groups. There are both high status differentials and high competition. An example of this is gentrification, where particular social groups create social and economic value through particular renovation practices (Thompson 2003; 1979[2017]). In such a society, power and status are constantly being realigned, through continual changes within the predominant category system. Within Rubbish Theory, this is a "class society." By contrast, if transfers from rubbish are prevented then status within a society and possession of material resources become separated. A situation with high status differentials, and low competition predominates. Thompson calls this a "caste society." An example is this is Indian Brahmins being accorded higher social status than those with greater material wealth (Thompson 1979[2017]:118). In such circumstances, moving between different castes becomes virtually impossible. The opposite of this is when there are no limits to what and when rubbish may be converted to durables. In such circumstances the durable category in effect disappears - if everything is durable (and valuable) then nothing is. What may then arise is an individualistic, competitive context with high competition and low status differentials, an "egalitarian society" in Rubbish Theory terms. Examples of this are classic depictions of Papua New Guinean 'big men' (Thompson 2003: 327). The fourth possibility (low competition, low status differentials) is asserted to exist or have existed among several societies, notably the Tibetan Sherpas and in the $18^{\text {th }}$ century Lake District of North-West England. This entails "a sort of easy-going and convivial yet unbeholden self-sufficiency" that is not necessarily communal, and is likely to be tolerant of wealth disparities (Thompson 2003: 327). ${ }^{4}$

\footnotetext{
${ }^{4}$ Returning to Bell (and Bird's) description of Indigenous life in Australia, perhaps a similar low status/low competition situation is extant? In the absence of detailed knowledge, I can only speculate.
} 
Thompson's argument is that this language (durables, transients, rubbish) may be applied across widely different systems. All orderings/worldviews/ontologies/discourse etc. may, in principle, be interpreted through this lens - we can interpret which items are fêted (durables), considered disposable (transients) and those that are moved out of sight (rubbish). Furthermore, by looking at the extent to which ordering systems are open to individual or group competition, it thus becomes possible to explore the on-going 'cosmopolitical dynamics' that emerge around social and environmental conflicts. Bringing this back to whales and whaling, in this article I use rubbish theory as a way to appreciate and illustrate how different 'objects' (whales, "nature" and the various products derived for them) are ordered and the concomitant valuations of these ordering practices. Within this narrative, I describe how particular ordering systems have been placed in competition and imposed in different contexts.

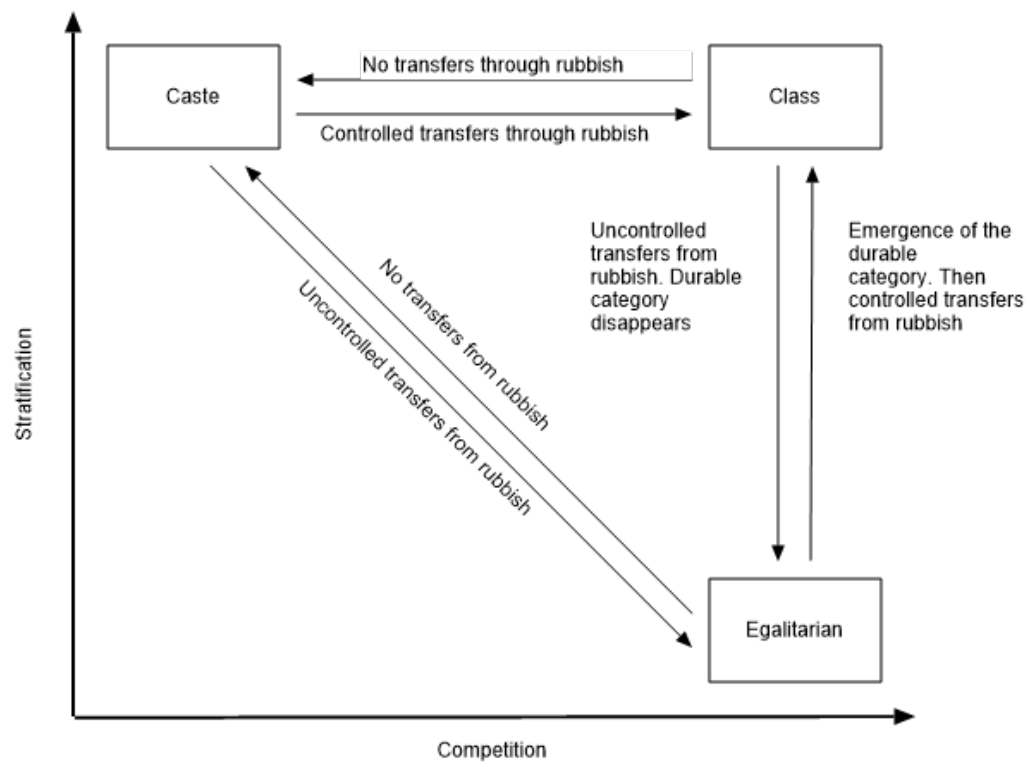

Figure 2: The Rubbish Triangle. Thompson 1979[2017]: 119

\section{Methods}

This article draws on writing on the sociology of orderings, which resembles the rubbish theory approach. In this approach, the social world is emergent within self-generating orderings (Law 2004: 15). This is ordering in the sense of control or management (Kendall and Wickham 2001: 21), the aspiration for which is something that sociologists have argued is integral to modernity (Law 1994). Objects are the focus of ordering projects and all objects are subject to multiple ordering projects, and ordering projects themselves can be objects. Ordering is thus a social and material process, a dynamic activity, with multiple ordering projects extant in any given situation. The narratives and stories humans construct about objects and the world are usually based on groups of overlapping ordering projects, termed modes of ordering (Kendall and Wickham, 2001: 4445). Ordering is an inherent part of human social life, but is not a neutral process. Enacting an ordering is a deeply political action - different agents struggle to enact their competing orderings of a situation. "Ordering always takes place in a contested space and, at the same time, paradoxically, the fact of such contestation makes ordering necessary" (Kendall and Wickham, 2001: 37). This is not simply a social process: orderings enmesh "a wide variety of objects, machines, systems, texts, non-humans, bureaucracies, times, without which 
[orderings] would not happen and could not become what [they are]" (Franklin, 2004: 279). Furthermore, different modes of ordering may interact or collide in unpredictable ways. As messy, on-going, imperfect, limited projects, one can assess their different implications - i.e. what do particular orderings enable or constrain and what is made known by an ordering?

Research on orderings generally follows three methodological protocols: "describe appearances", "describe the appearances of systems of thinking and knowledge" and "describe the uses of appearances" (Kendall and Wickham 2001: 79). This research seeks to do this drawing upon extant literature on whale-related conflicts. The narrative thus largely follows predominant orderings in the historical record - the rise of industrial whaling, the 1970s transition towards anti-whaling dominance, and the subsequent era of the moratorium on whaling, with continuing localized conflicts. I then examine the different systems of orderings identified by authors, be they discourses or ontologies, utilizing the rubbish theory schema. Where relevant, I also draw upon my own primary research activities, which have involved four months fieldwork in the Faroe Islands (Føroyar) and a study of ethical discussions by marine mammal scientists (cf. Singleton 2016c; Singleton \& Lidskog 2018). I do not, however, attempt to paint a definitive, comprehensive picture of whaling. Indeed, any picture painted is partial, given the human impossibility of stepping outside of ordering processes (Thompson 1979[2017]: 88-111). Instead, this research draws on the spirit of problematization (Alvesson and Sandberg 2011; Sandberg and Alvesson 2010).

In applying rubbish theory to historical and contemporary changes around human relationships with whales, I begin with the onset of modern whaling. Orderings of whales and whaling are presented at different times, broadly retelling the story of industrial whaling, the advent of green politics and the moratorium on whaling before focusing on contemporary conflicts around whales - those around whale-based tourism and around 'aboriginal subsistence whaling.' These are interpreted in turn, within rubbish theory's schema.

\section{How many blue whale units? The orderings of industrial whaling}

An account familiar to many, the rise and eventual collapse of the global whaling industry is a cautionary tale. In the 1860s, modern whaling (taken to have begun with the perfection of the explosive harpoon [Tønnessen and Johnsen 1982]), expanded across the world as new technologies rendered previously inaccessible whale stocks catchable (cf. York 2017). Over the course of the next one hundred years, many whale species and populations were hunted to or beyond the brink of extinction. With this precipitous decline, the industry itself was threatened, and regulatory measures were increasingly applied. After World War 2 (WW2) an international body, the International Whaling Commission (IWC) was set up largely due to the strong influence of the United States, and various initiatives, such as quotas, were advanced in order to rein in the whaling industry (Dorsey 2013). However, success was limited, with quotas proving ineffective and some whaling nations actively conspiring against them by falsifying catch data (Clapham \& Ivashchenko 2016; Heazle 2006; Ivashchenko, Clapham \& Brownell, Jr. 2011). Whaling thus became a fundamental issue for the nascent environmental movement. Integral to this story, were particular classifications of objects.

Broadly speaking for the bulk of this period and within the whaling industry, whales are best understood as collections of other objects. The primary product of the global whale industry was whale oil, with capitalists evidencing considerable creativity in marketing whale-based products (York 2017). Different whale species were valued according to the amount of oil they contained. This is most obvious in the infamous 'Blue Whale Unit' - that amount of oil an average blue whale held - which was the original unit of measurement used when quotas first came into existence. Whales were things known in a limited manner, as objects sighted, pursued, and secured: a series of by-products came from them, including oil, blubber and meat. Cetology, the scientific examination of whales and related species, largely took place aboard ships or on shore stations in this period. It was premised on the survival of whaling, and reflected industry interests (Burnett 2013). The realities of whaling ensured this - whalers were under economic pressure to maximize their outputs and this provided little opportunity for alternative understandings of whales to emerge (e.g. whales as persons). ${ }^{5}$ Whaling ships

\footnotetext{
${ }^{5}$ Although this is certainly not to suggest that this never occurred. Watanabe (2009) provides a moving description of an ex-whaler expressing sorrow and regret over the death of a whale with a calf. Likewise, Melville's Moby Dick provides a classic account of the mixed feelings whaling evoked among whalers.
} 
competed aggressively to capture as many whales as possible, securing a vital strategic resource as well as pushing toward new frontiers for exploration and empire (Epstein 2008; Roberts 2011; Tønnessen and Johnsen 1982).

In rubbish theory terms, the ordering system present during the 'heyday' of whaling largely reflects the situation of largely unfettered competition. There seem to be precious few 'durables' on display. Based on a "fundamentally exploitive" social norm (Epstein 2008: 86) whales appear largely transient items that disappear, to acquire other valuable if transient goods (oil). However, strange as it may seem, whales as discrete organisms were largely invisible. They form part of the 'residual rubbish' that was largely screened out by the socioeconomic system of whaling. It is tempting to see the carving of scrimshaws on whale bones by whalers as embodying this, i.e. a by-product repurposed as artistic canvas. Whales were simply part of the raw material from which transient items were produced, which could be exchanged for a durable, money. This was a situation characterized by low status differentials and no clearly imposed rules about when rubbish could be transferred to the durable category. As with other capitalist resource frontiers (cf. Tsing 2005), there was money to be made for 'self-made men' with the bravery and intelligence to seize opportunities. The extent to which whaling captains and ship owners were able to convert their wealth into social status onshore was varied. However, it seems fair to say that many were successful, contributing to the belief that whaling and whale products were integral to successful industrial and societal development (Dorsey 2013; Heazle 2006; Tønnessen and Johnsen 1982). For example, whaling played a prominent role in Japan's post-war reconstruction (Dorsey 2013), something that is credited with providing a nostalgia for whale meat among some "many of whom are convinced that whales saved them from a major famine" (Kalland 2009: 164). Indeed, after WW2, when many whale stocks were obviously endangered, several countries e.g. the Netherlands, prioritized whaling as an economic reconstruction activity, at times actively sabotaging regulation efforts (Heazle 2006).

This view and valuation of whales was not universally held. Groups in several parts of the world objected to the developing whale industry (Barthelmess 2006; Ringstad 2006). Some of these reflected alternative ways of valuing whales. For example, northern Norwegian fishers protested vociferously against whaling. These fishers asserted whaling was detrimental to their livelihoods, based on "popular perception of whalers as helpers in fishing effort", with whales thought to drive fish towards fishers (Barthelmess 2006: 148). Likewise, as time went on more voices asserted the industry was self-destructing. These failed for several reasons. Firstly, the competitive nature of the setting left people unwilling to be the first to submit to regulation (Tønnessen and Johnsen 1982). Secondly, in a situation of open competition lacking caste-like distinctions, it was hard for alternative voices to break through. This is illustrated by the case of Norwegian scientist Johan Hjort; a scientist deeply embedded in the whaling industry. Hjort found that his efforts to assert whale populations were declining were undermined by opponents who took 'common sense positions' contesting this (Roberts 2015: 145). Hjort found that his 'expertise' seldom outweighed that of others such as whale-boat captains (Singleton 2016a: 420). Within the social arenas of the whaling industry of the era from1860-1960 it is thus fair to suggest that the valuation system was largely interpellated with an open, competitive system. Epistemic authority accrued to those best able, through strength or guile, to assert their position. Indeed, it was only after many whale stocks were exhausted that the industrial whaling ordering was finally challenged (Epstein 2008).

\section{Saving whales: the anti-whaling ordering}

Coterminous with the travails of the increasingly ailing whaling industry, a significant environmental movement arose in many parts of the world. It took different paths in different places and has had variable success - in some places green parties now form a regular part of governing coalitions (e.g. Sweden or Germany) while elsewhere, they have been unable to gain traction within formal political processes (e.g. in the USA). Almost everywhere, however, environmental voices have been heard (Dryzek 2013). For the early green movement whaling was an important environmental issue for its own sake but also for its symbolic value. Whales thus became metonymic for nature itself and protection of whales to many is aligned with protection of 'wider nature' (Kalland 2009). Indeed, contemporary environmental organizations remain involved in antiwhaling activities to varying degrees. 
The big breakthrough around whaling for the nascent environmental movement was the 1972 United Nations Conference on the Human Environment, where the first calls were made for a moratorium on whaling (Epstein 2008: 107). Environmentalist voices subsequently became increasingly prominent at the IWC with, for the first time, some nations participating and even joining as 'anti-whaling countries.' The IWC expanded as a result. In this period, the IWC's Scientific Committee was arguably at its most influential (Aron 2001). Catch quotas were implemented on a species basis with some (heavily endangered) species receiving quotas of zero. Various management procedures were also instituted. A shift had occurred, and more and voices were raised against all whaling activities. In particular, despite the contradictions of US whaling policy, the US delegation was able to influence the direction of the IWC (Dorsey 2013). In 1982, a moratorium on whaling was passed, coming into force from the 1985-1986 whaling season. The moratorium, passed against the advice of the IWC's scientific committee, has remained in place ever since. The IWC Scientific Committee continues to debate ways to measure and manage whale stocks. In 1993 Scientific Committee chair Philip Hammond became a more modern counterpart to Johan Hjort when he resigned in frustration at how the Committee's expertise was treated (Kalland 2009: 122) The moratorium represents arguably one of the public high points of the international green movement. Whaling does continue in a more limited fashion, and remains a target for environmental activism.

The orderings of the conservation movement contrast markedly with that of the whaling industry. In the latter, 'nature' (in the form of whales) was conceived as a collection of resources for the production of mostly transient goods to be exchanged for durables. By contrast, 'nature' is ordered very differently by environmentalists; whilst acknowledging that the environmental movement has fragmented (cf. Jamison 2001), nature is considered the ultimate 'durable' object. Although, what nature is taken to consist of is variable within environmental orderings (Dryzek 2013). In the case of anti-whaling action, some groups seek to protect the lives of individual whales (cf. Singleton 2016c), while at other times, species, ecosystems and geographical areas are the priority. Likewise, there is disagreement about what damages nature. However, for the purposes of this article, it is fair to say that integral to all green action is some idea of nature as having value of itself. By contrast, many human actions (particularly capitalist industrial actions) depreciate 'virgin nature' through pollution, hunting, population growth, etc. In contrast to everlasting Gaia, human objects are largely ephemeral and allocated to the 'transient' category (e.g. Lovelock 1979 in Dryzek 2013: 199). The history of whaling illustrates the waxing of this particular ordering. As the previous Section shows, whales were collections of transient goods for over a hundred years, but from the 1970s onwards the view of nature as durables (and whales as their symbolic extension [cf. Kalland 1993]) increasingly predominated. Thus contemporary anti-whaling is of a different character to that of the Norwegian fishers described above, who were not advancing an idea of nature as durable, but rather saw the growth of whaling as a threat to their own ability to convert transient nature into various trade objects.

The period 1972-1986 is depicted by many social scientists as 'the best' for managing conflict around whaling (e.g. Aron 2001; Heazle 2006). The argument is that both pro- and anti-whaling views were articulated and heard within the IWC, and largely neutral scientific management was possible. By contrast, following the onset of the moratorium the picture painted is one of dysfunction and conflict, with limited substantive progress. Stepping aside from discussion of the validity of these claims (cf. Singleton 2016a for a summary), viewed through the lens of rubbish theory this is a tale of the power to manage the movement of objects from the rubbish to durable categories. The rise of the environmental movement led to the creation of a durable category for the first time (largely) around whales and whaling. Instead of being ordered as variety of transient raw materials, whales increasingly came to be ordered as objects in their own right or in aggregate form as 'populations' or 'species' forming part of 'ecosystems.' During the 1970s, the control of flows of objects was largely in the hands of scientists within the IWC Scientific Committee. Through their ordering practices (e.g. creating population estimates), it became possible for generic Blue Whale Units to become multiple, different 'endangered species.' Neither pro-whaling ('nature is transient', 'whales are rubbish') nor environmental ('nature is the durable', 'whales are nature') perspectives were totally dominant. Scientists were an important group in this stage, managing the transition between rubbish and durables. However, as time went by the environmental ordering was increasingly instituted (within the IWC at least) and whaling increasingly seen as destroying valuable durable objects. Whales' position in the schema became increasingly fixed. 


\section{The right kind of whale consumption? Whale watching}

It should be noted that just because environmental orderings designate 'nature' as durable, does not mean that 'nature' is not consumed in any way. Whales, as metonyms for nature, exemplify this point - contemporary whaling in all its forms remains a flashpoint environmental issue, in part because it represents the destruction of a durable, something that has to be maintained in perpetuity. However, as with historic buildings or fine art, it is permissible to consume whales in some forms, most prominently through whale-watching-based tourism. Indeed whale-watching is commonly framed a natural replacement for whaling, likely to generate more money (Cisneros-Montemayor et al. 2010; Corkeron 2004; Cunningham, Huijbens \& Wearing 2012; Hoyt 2001; Kuo, Chen \& McAleer 2012). Likewise, whaling negatively affects prospects for whale-based tourism (see Singleton 2018: 90-91 for an overview).

Generalizing, whale-watching typically involves groups of tourists paying to board a boat (often specially outfitted for the purpose) and being taken to a place where there is a high likelihood of seeing whales. This encounter is curated, with various people on board (e.g. the boat's captain or an affiliated biologist) directing participants' gazes towards items of interest, providing information on what is happening, and at times interpreting the observed animals' behavior. In many cases, participants are encouraged to come to know whales as individuals and to reflect on a general environmental message about humanity's role as a threat to nature. Such encounters can be interpreted as attempts to instill ecocentric values (Milstein 2008; 2011; Peace 2005). Often, whale-watching is a form of 'ecotourism.' Ecotourism is intended as a way to travel and enjoy the world without contributing to the destruction of the environment, also aiding local communities (Campbell et al. 2008: 200). This contrasts with 'ordinary' tourism, which is deemed to inherently involve destructive consumption of nature. In rubbish theory terms, ecotourism involves 'correct' consumption of durable nature, whereas ordinary tourism destroys the object consumed. The upshot of this is that whale-watching has become embroiled within a variety of political ecological conflicts. This has two consequences, which I take in turn.

Firstly, various actors make direct comparisons between whaling and whale-watching activities. This is the case in Iceland, where whaling is depicted as deleterious to growth of the tourism industry (Bertulli et al. 2016; Cunning, Huijbens \& Wearing 2012; Parsons \& Rawles 2003). By contrast, others assert that it is possible for the two industries to coexist (Rasmussen 2014). A respondent of mine illustrates the heated nature of the conflict between these two standpoints. While a PhD student, he had the unenviable experience of having his preliminary results on whale-watching impacts trumpeted by the right-wing Icelandic press, which placed his research (in conjunction with whale-watching boats) in temporary jeopardy. His findings were taken as evidence contesting the ordering that whale-watching represented 'consumption without destruction.' This links to the second consequence: ordering whale-watching as non-consumptive consumption makes discussion of the practice's impacts more heated and difficult. In a direct sense, boats (sometimes in fairly large numbers) following cetaceans may disturb animal lives and habitats. There is a body of research expressing concern that uncontrolled tourist activity is an increasing threat to whales (Christiansen et al. 2013; Higham \& Lusseau 2007). During the same project, I was also able to read a letter written by two scientists, Lars Bejder and David Lusseau, resigning from the IWC Scientific Committee's sub-committee on whale-watching. Among the reasons listed in the letter are sub-committee members having undeclared interests in whale-watching, who are accused of undermining scientific work "to ensure the rapid growth of whale-watching with little attention to long-term sustainability" (Bejder and Lusseau 2013). These interests conflict with the stated motives of the scientists, who try to produce "the best possible science to help guide the management of the sustainable exploitation of whales and dolphins for tourism."

The whale-watching industry, as ecotourism, also has environmental impacts in a broader sense. If tourism is an ordering with a particular orientation to the world, coproduced with the role of the tourist (Franklin 2004), the ecotourist is a further ordering, distinguishing between 'good' and 'bad' practices. Many political ecology scholars have problematized the distinction between ecotourism and tourism. These scholars assert that the ecotourism-tourism distinction simply conceals the environmental impacts of ecotourist activities either directly (damaging places visited) or in the form of the infrastructure (hotels, flights, etc.) that it requires (Meletis and Campbell 2007). Indeed, some scholars argue that the ecotourist-tourist distinction is actually more of a status symbol among different groups within (primarily western) society (Butcher 2003; Duffy 2002). In this depiction, wealthier, higher status individuals prefer expensive, 'green' ecotourism to destructive 'mass' 
tourism. This has been criticized as leading to a disproportionate focus on 'tourist-friendly' environments, rather than other potentially more ecologically important aspects of nature (cf. Dowie 2011; Duffy 2002).

From a rubbish theory perspective, it is tempting to suggest that there is an ongoing conflict about whales and nature as 'durables that are consumable.' Over the past fifty years, whale-watching has largely been ordered as an activity that does not damage 'durable' whales and nature, in part, due to contrasting it with destructive whaling. This is particularly obvious in the case in Iceland, where whale-watching and tourism generally now dwarf whaling. Various organizations, groups and individuals have emerged that facilitate the consumption of whales and nature. Tourist operators seek to distinguish their consumption of whales from that of whaling, thus facilitating the transfer of rubbish into durability. At the same time, with the rise of ecotourism, this form of nature consumption has become one of the ways particular social groups in society differentiate themselves from others, arguably forming part of a class system alongside consumption of other status symbols (cf. Thompson 1979[2017]). The growth of whale-watching and ecotourism more generally is arguably threatening its exclusivity, with the ubiquitous consumption of a durable damaging its status both materially and symbolically (cf. Neves 2011).

What thus emerges in Iceland is conflict between different groups seeking to enact their orderings. Whaling, whilst economically marginal, retains symbolic salience within nationalist orderings ${ }^{6}$, where the primary durable is the Icelandic state and its concomitant authority over the territory and waters that it claims (Brydon 1990; 1996; 2006). Pro-whaling actors at times show considerable creativity in associating whaling and whale consumption with 'Icelandic-ness.' As one example, on a 2015 trip to Iceland respondents pointed me towards a beer brewed with a whaling by-product, fin whale testicles (Figure 3). Brewed for the traditional calendar month of Porri, the month of frost, it was created to match the dried, smoked or fermented food consumed traditionally at that time. Contemporary whaling practice is thus ordered as part of Icelandic memoryscapes. 'Nature' in this ordering, is a collection of different objects (durable, transient and rubbish), some of which may employed in the maintenance of an Icelandic durable. When it comes to whale watching, Icelandic whalers and their advocates often seek to assert that whaling and whalers are morally equivalent as both consume transient nature, simultaneously positioned as upholders of the Icelandic durable object, rather than simply effecting the eventual conversion of transient objects into rubbish. There is a certain amount of evidence that this view is shared even in places where whale-watching is increasingly prominent. One article suggests that while marine mammal species in Iceland are increasingly appreciated as a source of revenue, there is little evidence that this appreciation has led to a broader reordering of nature (Einarsson 2009).

Naturally, the equivalence of whaling and whale-watching is often contested by whale-watching operators, who assert that their activities do not damage the durable objects that are whales and nature. This however then places whale-watching operations potentially at disagreement with scientists who raise concerns about unregulated growth of whale-watching operations. This latter conflict can be interpreted as not just about safeguarding the environment (or not), but also about who controls the rate through which rubbish is transformed into tourist objects. Scientists at times find themselves in similar situations, for example during whaling days - undermined by other 'experts' asserting a different ordering of reality. The scientists quoted above are arguing for the authority of one social group ('scientists') to determine when rubbish is converted to durable status and also what consumption levels a durable object ('whales') can sustain and what 'maintenance' activities (guidelines, whale-watching free areas) are necessary. They likewise likely find an ally in those societal groups that seek to retain the exclusivity of certain consumption practices. Together they are thus fighting for the maintenance of the 'nature as durable' category in order to prevent its collapse - if all nature can be exploited equally, none of it is particularly durable and worth maintaining. Likewise, it will cease to be a meaningful status signifier if unregulated consumption is allowed, threatening whales' (and nature's) durable status. It would thus be interesting to see if there are differences in exclusivity around the different Icelandic whale-watching operations.

\footnotetext{
${ }^{6}$ Similar claims are reported in many other whaling countries. For example, whaling has gained a formal place within the Japanese state, protected from market forces (Danaher 2002; Peace 2010).
} 


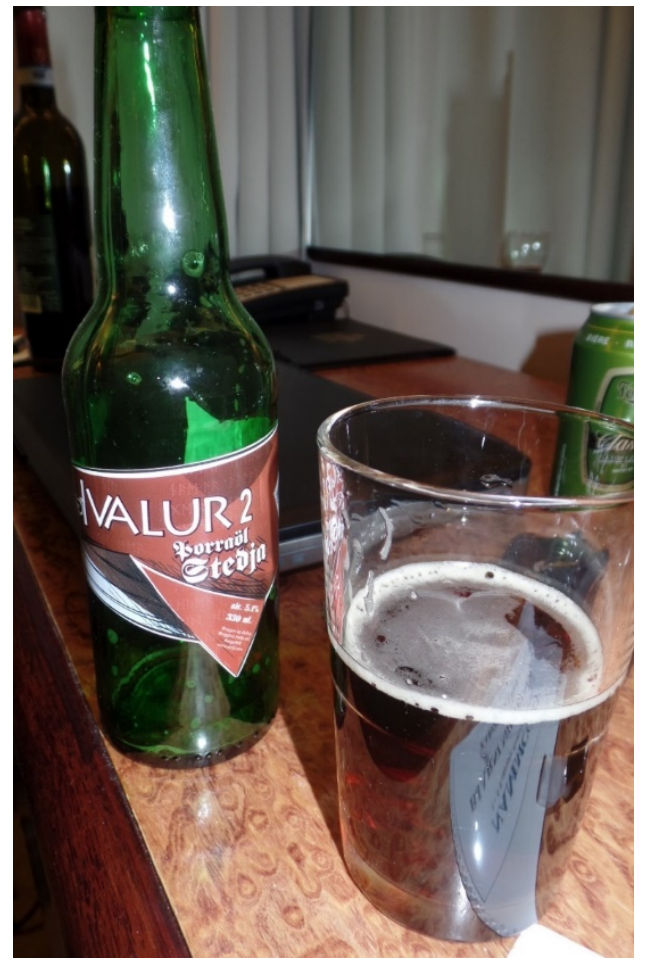

Figure 3: A bottle of Hvalur 2 beer. Source: Benedict Singleton

\section{The wrong kind of whale consumption? Makah whaling and other practices}

Despite the moratorium, whaling has continued in various parts of the globe. This has largely been as an insignificant economic activity, but one that retains considerable symbolic if not material salience to the populations of 'whaling nations' (Epstein 2008). Although disparate and diverse, all contemporary whaling orderings can to a certain extent be interpreted as reactions to the nature-as-durable ordering. This varies in practice. Some countries have simply refused to submit to the dominance of the environmentalist ordering at the IWC, and have left it. Canada and most recently Japan exemplify this. Other countries continue to pursue 'commercial whaling' within the IWC, having lodged objections to the moratorium, as is the case of Iceland and Norway. Others allow hunting of animals outside of the IWC's purview, as with Faroese pilot whale drives. Generalizing somewhat, proponents of these activities accept the principles of nature conservation but contest the view that human activity (and particularly whaling) is inherently damaging to nature's value. They argue that elevating whales as uniquely special over other animals is an act of cultural imperialism (Barsh 2001; Freeman 2001; Joensen 2009; Kalland 2009). In rubbish theory terms, the position whaling proponents take is understandable as an argument that killing whales does not inherently or irrevocably damage 'nature.' Indeed many whaling advocates are quick to point out other 'worse' activities perpetuated by people in other places. As such, even if (as anti-whalers suspect) some pro-whaling actors and groups do wish to enact a similar view of reality reminiscent of the heyday of whaling, as things stand they must at least pay lip service to the notion that nature is a durable that requires protection.

Previously, several countries (South Korea, Iceland and Japan) have taken advantage of the IWC rule that permits member countries to assign themselves whaling quotas for research purposes. Whilst highly controversial, these activities also entailed a reaction to contemporary environmentalist orderings. In defending or opposing such research, scientists argued about its value for environmental management, i.e. the sustainable use of nature (cf. Singleton and Lidskog 2018). In sum, all these different forms of whaling (reflecting different views about the natural environment) essentially accept the post-1972 ordering that 'nature' is a durable worth 
preserving, with conflict revolving around what does or does not do damage or what knowledge is needed. It is an argument about the maintenance of durable objects rather than their existence. Thus, in contrast to early twentieth century anti-whaling action in Norway, contemporary conflicts thus emerge over access to durables rather than access to transients. It is not about how one may exploit a transient object, it is about what action maintains/damages a durable.

There is another form of whaling permitted within the IWC that merits special attention as one of the ways that very different orderings encounter the environmental ordering of nature, 'aboriginal subsistence whaling.' Such practices occur where it is deemed that "whale products play an important role in the nutritional and cultural life of native peoples" (IWC 2020). At present, the IWC categorizes certain whaling activities in Greenland, Russia, St. Vincent and the Grenadines, and the USA with this label. For reasons of brevity, this Section focuses upon just one example of aboriginal subsistence whaling, the case of the Makah of Washington State, USA.

Historical and ethnographic descriptions of Makah lifestyles and culture, and those of neighboring groups, have emphasized the importance of whaling to both society and subsistence. However, after several hundred years, whaling activities ceased in the 1920s due to declining whale stocks (brought about by commercial whaling for oil). In the 1990s, as part of a wider cultural revival process, representatives of the Makah sought to resume limited whaling utilizing arguments that the treaty they signed with the US had guaranteed them this right. The story itself is long and fascinating. To put it simply the Makah (by no means united internally about the rightness of their actions) reconstructed a method for whaling combining historic (hand-crafted paddle canoe and whaling spear) and contemporary (a specially adapted rifle) technologies (Coté 2010; Erikson 1999; Van Ginkel 2004; Sullivan 2000). They also drew on various cultural traditions and behaviors around whaling that had previously declined. In 1999, a grey whale (Eschrichtius robustus) was hunted and killed. This act took place in a state of uproar, with numerous conservation groups outraged. Various actions took place, including attempts to interfere with the whale hunt itself. Subsequent whaling efforts have been embroiled in legal challenges. An illegal hunt subsequently took place in 2007, with participants serving gaol time (Beldo 2019).

The literature on Makah whaling highlights several things: firstly the high status of whaling as the preserve of high ranked members of society (who would demonstrate their largesse through potlatches). Historically, Makah society was stratified, with families jealously guarding 'their' ritual knowledge and songs. Sorting out this complex body of custom and belief into neat 'shared Makah knowledge' was indeed one of the challenges of the cultural revival process (Beldo 2019; Van Ginkel 2004). Secondly, whales, whilst prized as the sources of various other objects (meat, whalebone, blubber, oil, etc.), were not seen in the same way as by international whaling companies in the nineteenth and twentieth centuries. In Makah thought, whales were not simply collections of other objects but also individuals in social relationships with hunters and (human and nonhuman) society. Historic (and contemporary) Makah whalers are expected to prepare physically, mentally, morally, spiritually and socially (because whaling is a collective effort) even if practices and their meanings do vary (Beldo 2019). Likewise, relationships within the community also affect a hunt's chances: whalers' wives spiritually connected to the whales - should seclude themselves while a hunt is on to ensure success and safety (Beldo 2019: 105-106). Within this worldview, if the preparations are correct then the whale will offer itself to the whaler. Indeed, in 1999, the whale was seen to approach the whaling canoe, which Makah whalers interpreted as the whale rewarding them for their deeds (Beldo 2019: 1). The idea of a hunted animal offering itself to the morally and physically correct hunter has been observed among other North American indigenous groups (Nadasdy 2007; Sakakibara 2020). Likewise, Makah cosmology echoes certain indigenous ideas elsewhere in the Americas that humans are entwined with nature and 'nature' also consists of different kinds of other-than-human persons (e.g. De La Cadena 2010). ${ }^{7}$

Looked at through the lens of rubbish theory, Makah whaling resembles ecocentred, environmentalist orderings in that the society is interwoven with nature and furthermore represents a durable object, to be conserved in principle forever. This is unsurprising, and influential environmental thinkers often take

\footnotetext{
${ }^{7}$ Interestingly, "webs of reciprocity linking whales and whalers" are also reported from Japanese whaling (Kalland 2009:
} 152). 
inspiration from indigenous peoples the world over and indeed, indigenous peoples are sometimes taken to be 'natural conservationists' (Krech 1999). Initially it seems odd that Makah whaling elicited such a violent reaction from the wider US and non-whaling international community. I believe, as ever, that the devil is in the detail.

As noted above, Makah assert their right to whale within the category of aboriginal subsistence whaling. Its existence within the IWC is the product of contradictions in US whaling policy. The US is an anti-whaling nation in sentiment and takes an anti-whaling stance at the IWC, however at the same time, the US represents various indigenous peoples at the IWC, several of whom wish to hunt whales and indeed many groups hold treaty rights to do so (Dorsey 2013; Reeves 2002). Thus at a domestic level, Makah whaling has been the focus of legal challenges from all sides in a bid to decisively assert which are the most important durables - a potential sub-population of grey whales, or Makah cultural enactments (Beldo 2019).

In asserting the rights of indigenous peoples at the IWC, the US is also enacting a wider ordering of the cultures of the world around indigeneity. Historically, many indigenous peoples and cultures were dismissed as backward, savage and ignorant; doomed to be swept aside by waves of progress in the form of largely white, European cultures, lifestyles and economies. An example of this is the myth of the "vanishing Indian" doomed to dwindle into extinction in the minds of colonial administrators (Berry 1960; cf. Said 1979). Within orderings of Empire, culture and practices of 'the native' were at times considered at best transient and at worst rubbish to be moved onto particular 'reserves' out of European sight and mind. Indeed, numerous indigenous cultural forms and movements that arose following imperial contact can be interpreted as active efforts by indigenous people to take objects designated by colonizers as 'rubbish' (e.g. local knowledge, cosmologies and technologies) and reform them into durables. This process occurred in different times and places. For example, the diverse Melanesian movements dismissively labelled "cargo cults" (Lindstrom 1993) or local messianic religious movements such as the Lakota Ghost Dance (DeMallie 1982). These may draw derision from the colonial oppressor (and their allies) but this is at least in part because they often represent a direct challenge to the system of durables, transients and rubbish imposed by colonizers. Such cultural work binds new and old objects into cosmologies, often in the face of overt opposition or oppression. In the contemporary era, on the back of various anticolonial movements, indigenous culture and sovereignty have been resurgent, with indigenous knowledge and lifestyles, contemporary and ancient, increasingly appreciated as durables to be maintained and preserved (cf. Jentoft, Minde \& Nilsen 2003). For example, Swedish Sami peoples have asserted their rights, language and culture and, amongst other things, successfully accrued a role within the management of Laponia national park (Green 2009). Furthermore, where they have intersected with environmentalism, indigenous activists have often found allies, and indigenous and local people have increasingly been seen as knowledgeable 'co-managers' of natural resources and areas.

Where does this leave Makah whalers? While it is important not to oversimplify anti-whaler actions as simple racism (Beldo 2019), it is tempting to see the violent reaction to Makah whaling as linked to their failure to conform to the 'correct' behavior of indigenous people within dominant societal orderings (cf. Coté 2010). This ordering essentializes certain practices as more or less worthwhile when carried out by different societal groups. Critics of this perspective argue that this involves reifying a romantic, ahistorical ideal about indigenous mind-sets and lifestyles (Barsh 2001; Krech 1999; Freeman 2001). Such processes have also been linked to ongoing 'cultural violence' against indigenous people who do not confirm to mainstream societal stereotypes (Maddison 2013). So for example, the fact that the Makah used a rifle and modern support boats was evidence of the 'inauthenticity' of their practices. As such, Makah orderings present a challenge on a number of levels. Firstly, they crossed a line by killing a creature seen as symbolic for the ultimate durable, nature, in many contemporary societies. They crossed a second line by not conforming to the permitted ritual ways for killing a whale - their technology was 'too modern'. ${ }^{8}$ This damaged two "universal" societal durables (i.e. pertaining everywhere, cf. Tsing 2005: 7) - nature and 'pure' indigenous culture.

By contrast, to most Makah, their whaling activities were the enactment of their own ordering. The successful hunting of a grey whale, with meat distributed within the community was the maintenance of an alternative 'ultimate durable' - the 'correct' balance of (caring) relations between human and non-human kin based on their valuation system, which pertains in their area (cf. Martello 2004). In the Makah controversy,

\footnotetext{
${ }^{8}$ Nor was it 'for science.'
} 
what are being asserted are two conflicting class-systems (in rubbish theory's language, above), interpellated with particular orderings of whale consumption. Within 'mainstream' US (and international) orderings, whales may be consumed in certain ways: through whale-watching or in 'traditional' ways. By contrast, in many Makah orderings, consumption of whales through hunting is the right of all Makah, and the method is their own choice. Conflict is thus over which particular groups in society may govern the consumption of durable whales.

\section{Concluding discussion}

The foregoing sections have described how very different orderings of whales have existed throughout history, from collections of raw materials to beings to be interacted with, as well as symbols of greater wholes. In terms of rubbish theory, whales moved from collections of transient materials on the way to rubbish, to various forms of durables. Conflicts have thus changed in nature, to be about what the durable 'nature' is and how to consume it. So far, and so similar to many other political ecological accounts - different orderings/ontologies/discourses/frames/worldviews clash and representation/enactment of reality is at the heart of things. The reader is therefore justified in wondering what rubbish theory actually adds. I argue that it has two main advantages:

Firstly, I believe that rubbish theory aids comparison. Typically, accounts of conflicts between different worldviews stress their incommensurability. By contrast, rubbish theory provides a shared language. I would suggest that accounts of many environmental conflicts, for example issues relating to the drawing and enforcement of boundaries of 'nature' around nature reserves, are readily understandable with rubbish theory (e.g. Neumann 2002). Conflicts emerge repeatedly over what 'nature' is and its consumption, and whether other durable objects (such as local culture and practice) are extant. By focusing on the extent that status and the movement of goods it becomes possible to focus analysis. Thus, most contemporary cetacean conflicts enact roles described by rubbish theory, questioning who has rights to move objects into the durable category - should it be local hunters/tourist entrepreneurs, or should it be 'scientists'? Similarly, how much transfer is permitted and when? Looking at how ordering systems become more or less 'open' through time will likely shed light on the processes by which radical movements (e.g. environmentalism or 'indigenous rights') become co-opted and/or institutionalized (cf. Burman 2020; 2017). Likewise, it generates insight into how class and caste systems (with concomitant rights to consume objects) are enacted and altered.

The second advantage relates to the nature of the rubbish category itself. Rubbish theory explicitly acknowledges the existence of 'the residual' beyond human ordering projects. Within rubbish theory analysis, it is important to maintain the distinction between 'transient' and 'rubbish' (although of course in practice this may present challenges). Transient objects have value, they just depreciate with time/use to rubbish. By contrast, rubbish has zero value and represents 'that which is eliminated' within ordering practices. It thus also represents the residual of the universe outside of human theoretical lenses, and thus represents the raw stuff for future orderings. Transient objects and rubbish thus have somewhat different characteristics. Rubbish is often what is to hand when social actors try to alter the rubbish theory schema. This is perhaps one of the reasons that whales came to be symbolic of both the environmental movement and nature itself. One could point to certain attributes of particular cetacean species (intelligence, social natures, etc.) but this misses one part of the story: the actions of the environmental movement rescued whales from the rubbish dump, repackaging them as nature's avatars. This "super-whale" largely conflates the characteristics and contexts of 89 species of cetacean (Kalland 1993; Singleton 2019). For sure, while other animals (e.g. elephants or great apes) may at times be discussed in similar terms to whales (cf. Singleton 2016b) it has seldom proved possible to order such a diverse group of animals and species in such a way (cf. Freeman \& Kreuter 1994). Whales' status as (often literally) rendered industrial by-products (i.e. "rubbish") left them almost uniquely placed for transformation into the durable symbol of the environment.

There is a third, broader point we can take from these two advantages. Rubbish theory is a potential tool for constructively engaging with divergent orderings/ontologies/discourses/frames/worldviews. Firstly, by highlighting what different orderings value or miss. We can see in the cases above that framing 'nature' as a global durable object repeatedly clashes with socio-material orderings where 'Iceland' or 'Makah-nature relationships' are ordered as timeless durables. My point is that rubbish theory helps enable the discovery of 
"crossings" (Blaser 2018: 61) or "property clusters" (Ludwig 2016: 44). It thus represents a step towards 'agonistic cosmopolitics' (cf. Blok 2011). As noted above, it also can help assess the potential effects of particular moves in conflicts rooted in part in ontological difference and in power asymmetries.

For example, Blaser describes how a precipitous decline in Caribou numbers precipitated a conflict between state authorities instituting a ban on hunting and Innu people in Canada (2018). Blaser's proposed solution is Innu being permitted limited hunting under strict managed traditional protocols. This can be understood as an attempt to bridge the different ordering systems at a crossing point. For the Innu, the durable object that requires maintenance and protection is atiku, a word standing both for caribou and the relationship between Innu and caribou. By contrast, to wildlife managers the caribou population is the durable object. Blaser's proposed solution better suits both ordering systems. Firstly, because it allows Innu to maintain and repair their relationship with atiku. Secondly, Blaser argues strict Innu regulation and enforcement of atiku will do less damage to the caribou population than Innu simply ignoring the hunting ban. In essence, he advocates a shared object system where both 'nature' (in the form of caribou populations) and atiku are maintained by allowing hunting only when subject to strict Innu rules.

A key question, however, will then be who is allowed to define strict Innu rules? Lacking clear information on the Innu case myself, I feel the Makah example above highlights that the definition of 'Innu rules' will be key to the initiative's success both within Innu communities and among wildlife managers. Both groups will need to be satisfied in according power to those tasked with converting residual rubbish into the durable category. In accounts of the Makah, pro-whalers resent the idea of conforming to outsider perceptions of indigeneity. As such, it will be interesting to see how Innu and wildlife managers negotiate such a tension with attention paid to how social status and material resources are distributed.

To round things off, it is important to acknowledge that what I have presented above is a sketch. Further applications of rubbish theory are required to assess its utility, which should be conducted on all social scales, from individual practices to international forums. I would also argue that the combination of rubbish theory with insights from Mary Douglas' cultural theory, with which Thompson was also involved, may also generate insight. The former examines, among other things, the performance of different forms of social relations (Thompson 2003). There seems to be an appetite for finding ways to balance cultural relativity with comparability (Blaser 2018; Bormpoudakis 2019; Ludwig 2016). Richard Thompson, while a member of Fairport Convention, wrote "To see both sides of a quarrel is to judge without hate or alarm." In this spirit, I believe rubbish theory provides one path for navigating the pluriverse.

\section{References}

6, P. \& P. Richards. 2017. Mary Douglas: understanding social thought and conflict. Oxford: Berghahn.

Alvesson, M. \& J. Sandberg. 2011. Generating research questions through problematization. The Academy of Management Review 36(2): 247-271.

Aron, W. 2001. Science and the IWC. In Friedheim, R.L. (ed.). Toward a sustainable whaling regime. Edmonton: Canadian Circumpolar Institute. Pp. 105-122.

Barsh, R.L. 2001. Food security, food hegemony, and charismatic animals. In Friedheim, R.L. (ed.). Toward a sustainable whaling regime. Edmonton: Canadian Circumpolar Institute. Pp. 147-179.

Barthelmess, K. 2006. An international campaign against whaling and sealing prior to World War One. In Ringstad, J.E. (ed.). Whaling and history II. Sandefjord: Sandefjordmuseene. Pp. 147-165.

Bejder, L. \& D. Lusseau. 2013. Regarding: whale-watching at the International Whaling Commission. Manuscript.

Beldo, L. 2019. Contesting Leviathan: activists, hunters, and state power in the Makah whaling conflict. Chicago: University of Chicago Press.

Bell, L. 2018. Place, people and processes in waste theory: a global South critique. Cultural Studies 33(1): 98121.

Berry, B. 1960. The myth of the vanishing Indian. Phylon 21(1): 51-57. 
Bertulli, C.G., R.H. Leeney, T. Barreau and D.S. Matassa. 2016. Can whale-watching and whaling co-exist? Tourist perceptions in Iceland. Journal of the Marine Biological Association of the United Kingdom 96(4): 969-977.

Blaser, M. 2009. The threat of the Yrmo: the political ontology of a sustainable hunting program. American Anthropologist 111(1): 10-20.

Blaser, M. 2018. Doing and undoing caribou/Atiku: diffractive and divergent multiplicities and their cosmopolitical orientations. Tapuya: Latin American Science, Technology and Society 1(1): 47-64.

Blok, A. 2008. Contesting global norms: politics of identity in Japanese pro-whaling countermobilization. Global Environmental Politics 8(2): 39-66.

Blok, A. 2011. War of the whales: post-sovereign science and agonistic cosmopolitics in Japanese-global whaling assemblages science. Technology \& Human Values 36(1): 55-81.

Bormpoudakis, D. 2019. Three implications of the political ecology of conservation. Journal of Political Ecology 26: 545-566.

Brydon, A. 1990. Icelandic nationalism and the whaling issue. North Atlantic Studies 2(1-2): 185-191.

Brydon, A. 1996. Whale-siting: spatiality in Icelandic nationalism. In Pálsson, G. \& P.E: Durrenberger (eds.). Images of contemporary Iceland: everyday lives and global contexts. Iowa City: University of Iowa Press. Pp. 25-45.

Brydon, A. 2006. The predicament of nature: Keiko the whale and the cultural politics of whaling in Iceland. Anthropological Quarterly 79(2): 225-260.

Burman, A. 2017. The political ontology of climate change: moral meteorology, climate justice, and the coloniality of reality in the Bolivian Andes. Journal of Political Ecology 24: 921-938.

Burman, A. 2020. Black hole indigeneity: the explosion and implosion of radical difference as resistance and power in Andean Bolivia. Journal of Political Power 13(2): 1-22.

Burnett, D.G. 2013. The sounding of the whale. Chicago: The University of Chicago Press.

Butcher, J. 2003. The moralisation of tourism. London: Routledge.

Campbell, L.M., N.J. Gray \& Z.A. Meletis. 2008. Political ecology perspectives on ecotourism to parks and protected areas. In Hanna, K.S., D.A. Clark \& S.S. Slocombe (eds.). Transforming parks and protected areas. London: Routledge. Pp. 200-221.

Chappell, P. 2013. Paper routes: "Bleak House", rubbish theory, and the character economy of realism. ELH 80(3): 783-810.

Christiansen, F., M. Rasmussen \& D. Lusseau. 2013. Whale watching disrupts feeding activities of minke whales on a feeding ground. Marine Ecology Progress Series 478: 239-251.

Cisneros-Montemayor, A.M., U.R. Sumaila, K. Kaschner \& D. Pauly. 2010. The global potential for whale watching. Marine Policy 34(6): 1273-1278.

Clapham, P.J. \& Y.V. Ivashchenko. 2016. Stretching the truth: length data highlight falsification of Japanese sperm whale catch statistics in the Southern Hemisphere. Royal Society Open Science 3(9): 160516.

Corkeron, P.J. 2014. Human attitudes and values: tradition and transformation and zombies. In Higham, J. E. S., L. Bejder \& R. Williams (eds.). Whale-watching: sustainable tourism and ecological management. Cambridge: Cambridge University Press. Pp. 48-56.

Coté, C. 2010. Spirits of our whaling ancestors: revitalizing Makah and Nuu-chah-nulth traditions. Seattle: University of Washington Press.

Danaher, M. 2002. Why Japan will not give up whaling. Pacifica Review: Peace, Security \& Global Change 14(2): 105-120.

Demallie, R.J. 1982. The Lakota Ghost Dance: an ethnohistorical account. Pacific Historical Review 51(4): 385-405.

De La Cadena, M. 2010. Indigenous cosmopolitics in the Andes: conceptual reflections beyond "politics". Cultural Anthropology 25(2): 334-370. 
Douglas, M. 1966[2002]. Purity and danger: an analysis of concepts of pollution and taboo. Abingdon: Routledge.

Dorsey, K. 2013. Whales and nations: environmental diplomacy on the high seas. Seattle: University of Washington Press.

Dowie, M. 2011. Conservation refugees. Cambridge, MA: MIT Press.

Dryzek, J.S. 2013. The politics of the earth. Oxford: Oxford University Press.

Duffy, R. 2002. Trip too far: ecotourism, politics and exploitation. London: Earthscan.

Einarsson, N. 2009. From good to eat to good to watch: whale watching, adaptation and change in Icelandic fishing communities. Polar Research 28(1): 129-138.

Epstein, C. 2008. Power of words in international relations: birth of an anti-whaling discourse. Cambridge, MA: MIT Press.

Erikson, P.P. 1999. A-whaling we will go: encounters of knowledge and memory at the Makah Cultural and Research Center. Cultural Anthropology 14(4): 556-583.

Escobar, A. 1999. After nature: steps to an antiessentialist political ecology. Current Anthropology 40(1): 1-30.

Fisher, D. \& B. Smiley. 2015. Adapting rubbish theory for heritage tourism. Journal of Heritage Tourism 11(2): 143-154.

Franklin, A. 2004. Tourism as an ordering: towards a new ontology of tourism. Tourist Studies 4(3): 277-301.

Freeman, M.M.R. \& U.P. Kreuter (eds.). 1994. Elephants and whales: resources for whom? Basel: Gordon and Breach.

Freeman, M.M.R. 2001. Is money the root of the problem? Cultural conflict in the IWC? In Friedheim, R.L. (ed.). Toward a sustainable whaling regime. Seattle: University of Washington Press. Pp. 123-146.

Gagnert Dalgren, D. 2019. I dag införs tiggeriförbudet - här är områdena som berörs. Ekuriren 1 August 2018, available at https://ekuriren.se/nyheter/eskilstuna/i-dag-infors-tiggeriforbudet-har-ar-omradena-somberors-sm5199802.aspx [accessed 7 May 2020].

Green, C. 2009. Managing Laponia: a World Heritage as an arena for Sami ethno-politics in Sweden. Ph.D dissertation. Uppsala University.

Heazle, M. 2006. Scientific uncertainty and the politics of whaling. Seattle and London/Edmonton: University of Washington Press/Canadian Circumpolar Institute Press.

Higham, J.E.S. \& D. Lusseau. 2007. Urgent need for empirical research into whaling and whale watching. Conservation Biology 21(2): 554-558.

Hoyt, E. 2001. Whale watching 2001. London: IFAW.

Ivashchenko, Y.V., P.J. Clapham \& R.L. Brownell, Jr. 2011. Soviet illegal whaling: the devil and the details. Marine Fisheries Review 73(3): 1-19.

IWC. 2020. Aboriginal Subsistence Whaling, available at http://iwc.int/aboriginal [accessed 29 May 2020].

Jamison, A. 2001. The making of green knowledge. Cambridge: Cambridge University Press.

Jentoft, S., H. Minde \& R. Nilsen (eds.). 2003. Indigenous peoples: resource management and global rights, Delft: Eburon.

Joensen, J.P. 2009. Pilot whaling in the Faroe Islands. Torshavn: Fróðskapur. Faroe University Press.

Kalland, A. 1993. Management by totemization: whale symbolism and the anti-whaling campaign. Arctic 46(2): 124-133.

Kalland, A. 2009. Unveiling the whale: discourses on whales and whaling. New York: Berghahn.

Kendall, G. \& G. Wickham. 2001. Understanding culture. Thousand Oaks, CA: SAGE.

Krech, S. 1999. The ecological Indian: myth and history. New York: W.W. Norton \& Company.

Kuo, H.-I., C.-C. Chen \& M. Mcaleer. 2012. Estimating the impact of whaling on global whale-watching. Tourism Management 33(6): 1321-1328.

Latour, B. 2004. Whose cosmos, which cosmopolitics? Comments on the peace terms of Ulrich Beck. Common Knowledge 10(3): 450-462. 
Law, J. 1994. Organizing modernity. Oxford: Blackwell.

Law, J. 2004. After method: mess in social science research. Abingdon: Routledge.

Lindstrom, L. 1993.Cargo cult: strange stories of desire from Melanesia and beyond. Honalulu: University of Hawaii Press.

Lovelock, J.E. 1979. Gaia: a new look at life on earth. Oxford University Press: Oxford.

Ludwig, D. 2016. Overlapping ontologies and indigenous knowledge. From integration to ontological selfdetermination. Studies in History \& Philosophy of Science 59: 36-45.

Maddison, S. 2013. Indigenous identity, 'authenticity' and the structural violence of settler colonialism. Identities 20(3): 288-303.

Martello, M. 2004. Negotiating global nature and local culture: the case of Makah whaling. In Jasanoff, S. \& M. Martello (eds.). Earthly politics. Cambridge, MA: The MIT Press.

Marwoto, I. 2019. From rubbish to cultural identity; making archaeology relevant for the contemporary community. Wacana 20(2).

Meletis, Z.A. \& L.M. Campbell. 2007. Call it consumption! Re-conceptualizing ecotourism as consumption and consumptive. Geography Compass 1(4): 850-870.

Milstein, T. 2008. When whales "speak for themselves": communication as a mediating force in wildlife tourism. Environmental Communication: a Journal of Nature and Culture 2(2): 173-192.

Milstein, T. 2011. Nature identification: the power of pointing and naming. Environmental Communication: a Journal of Nature and Culture 5(1): 3-24.

Morrell, B., W. Lipworth, R. Axler, I. Kerridge \& M. Little. 2011. Cancer as rubbish: donation of tumor tissue for research. Qualitative Health Research 21(1): 75-84.

Nadasdy, P. 2007. The gift in the animal: the ontology of hunting and human-animal sociality. American Ethnologist 34(1): 25-43.

Nadasdy, P. 2011. "We don't harvest animals; we kill them" agricultural metaphors and the politics of wildlife management in the Yukon. In Goldman, M.J., P. Nadasdy \& M.D. Turner (eds.). Knowing nature: conversations at the intersection of political ecology and science studies. Chicago: University of Chicago Press. Pp. 135-151.

Neumann, R.P. 2002. Imposing wilderness. Berkeley: University of California Press.

Neves, K. 2011. Cashing in on cetourism: a critical ecological engagement with dominant E-NGO discourses on whaling, cetacean conservation, and whale watching. In Brockington, D. \& R. Duffy (eds.). Capitalism and conservation. Chichester: Wiley-Blackwell. Pp. 251-273.

Parsons, E.C.M. \& C. Rawles. 2003. The resumption of whaling by Iceland and the potential negative impact in the Icelandic whale-watching market. Current Issues in Tourism 6(5): 444-448.

Parsons, L. 2007. Rubbish theory exploring the practices of value creation. In Borghini, S., M.A. Mcgrath \& C. Otnes (eds.). E-European advances in consumer research. Duluth: Association for Consumer Research. Pp. 390-393.

Peace, A. 2005. Loving Leviathan: the discourse of whale-watching in Australian ecotourism. In Knight, J. (ed.). Animals in person. Oxford: Berg. Pp. 191-210.

Peace, A. 2010. Speaking of whales: from totemizing the humpback to demonizing the Japanese. In Ringstad, J.E. (ed.). Whaling and history III. Sandefjord: Vestfoldmuseeine IKS, avdeling Hvalfangstmuseum Pp. 183-194.

Rasmussen, M. 2014. The whaling versus whale-watching debate: the resumption of Icelandic whaling. In Higham, J.E.S., L. Bejder \& R. Williams (eds.). Whale-watching: sustainable tourism and ecological management. Cambridge: Cambridge University Press. Pp. 81-94.

Reeves, R.R. 2002. The origins and character of 'aboriginal subsistence' whaling: a global review. Mammal Review 32(2): 71-106.

Ringstad, J.E. 2006. Bjarne Aagaard and his crusade against pelagic whaling in the late 1920s. In Ringstad, J.E. (ed.). Whaling and history II. Sandefjord: Sandefjordmuseene. Pp. 167-178. 
Roberts, P. 2011. The European Antarctic. New York: Palgrave Macmillan.

Roberts, P. 2015. The friend who outstayed his welcome? Johan Hjort and the difficulties of bringing science to bear upon whaling. In Ringstad, J.E. (ed.). Whaling and history IV. Sandefjord: Vestfold Museene IKS. Pp. 139-149.

Rose, D.B. 2003. Decolonizing the discourse of environmental knowledge in settler societies. In Hawkins, G. \& S. Muecke (eds.). Culture and waste. Lanham: Littlefield Publishers. Pp. 53-72.

Said, E.W. 1979. Orientalism. New York: Vintage Books.

Sakakibara, C. 2010. Kiavallakkikput agviq (into the whaling cycle): cetaceousness and climate change among the Iñupiat of Arctic Alaska. Annals of the Association of American Geographers 100(4): 1003-1012.

Sandberg, J. \& M. Alvesson. 2010. Ways of constructing research questions: gap-spotting or problematization? Organization 18(1): 23-44.

Singleton, B.E. 2016a. Clumsiness and elegance in environmental management: applying cultural theory to the history of whaling. Environmental Politics 25(3): 414-433.

Singleton, B.E. 2016b. Framing a Supermantra: ecotourism, engagement and conceptualisations of 'good' development. Forum for Development Studies 43(3): 463-487.

Singleton, B.E. 2016c. Love-iathan, the meat-whale and hidden people: ordering Faroese pilot whaling. Journal of Political Ecology 23: 26-48.

Singleton, B.E. 2018. Making a meal of it: a political ecology examination of whale meat and tourism. In Kline, C. (ed.). Tourism experiences and animal consumption: contested values, morality and ethics. London: Routledge. Pp. 87-101.

Singleton, B.E. 2019. The evolution of the super-whale: complexity and simplicity in environmental communication. Marine Policy 99: 170-172.

Singleton, B.E. \& R. Lidskog. 2018. Science, red in tooth and claw: whaling, purity, pollution and institutions in marine mammal scientists' boundary work. Environment and Planning E 1(1-2): 165-185.

Sullivan, R. 2000. A whale hunt: the remarkable story of a tribe's quest to regain its ancient rituals in the modern world. London: Headline Book Publishing.

Thompson, C. 2002. When elephants stand for competing philosophies of nature: Amboseli National Park, Kenya. In Law, J. \& A. Mol (eds.). Complexities: social studies of knowledge practices. Durham, NC: Duke University Press.

Thompson, M. 1979[2017]. Rubbish theory: the creation and destruction of value. London: Pluto Press.

Thompson, M. 2003. Time's square: deriving cultural theory from rubbish theory. Innovation: The European Journal of Social Science Research 16(4): 319-330.

Tsing, A.L. 2005. Friction. Princeton: Princeton University Press.

Tønnessen, J.N. \& A.O. Johnsen. 1982. The history of modern whaling. London: C. Hurst \& Co. Ltd.

Van Ginkel, R. 2004. The Makah whale hunt and Leviathan's death: reinventing tradition and disputing authenticity in the age of modernity. Etnofoor 17(1/2): 58-89.

Vaughan, D. 2016. The Challenger launch decision: risky technology, culture, and deviance at NASA. Chicago: University of Chicago Press.

Verweij, M., M. Thompson \& C. Engel. 2011. Clumsy conclusions: how to do policy and research in a complex world. In Verweij, M. \& M. Thompson Clumsy solutions for a complex world. Basingstoke: Palgrave Macmillan. Pp. 241-249.

Vigh, H.E. \& D.B. Sausdal. 2014. From essence back to existence: anthropology beyond the ontological turn. Anthropological Theory 14(1): 49-73.

Viveiros De Castro, E. 2004. Perspectival anthropology and the method of controlled equivocation. Tipití: Journal of the Society for the Anthropology of Lowland South America 2(1): 3-20.

Watanabe, H. 2009. Japan's whaling. Melbourne: Trans Pacific Press.

York, R. 2017. Why petroleum did not save the whales. Socius: Sociological Research for a Dynamic World 3. 